\title{
Stereological study of the elastic fiber and smooth muscle cell system in the bovine and buffalo penis ${ }^{1}$
}

\author{
Ilma C.A. Ribeiro², Marcelo Abidu-Figueiredo ${ }^{3}$, Fabíola B. Costa ${ }^{4}$ Marco A. Pereira- \\ -Sampaio ${ }^{4}$ and Maurício A. Chagas ${ }^{4 *}$
}

\begin{abstract}
Ribeiro I.C.A., Abidu-Figueiredo M., Costa F.B., Pereira-Sampaio M.A. \& Chagas M.A. 2013. Stereological study of the elastic fiber and smooth muscle cell system in the bovine and buffalo penis. Pesquisa Veterinária Brasileira 33(Supl.1):107-112. Laboratorio de Biomorfologia Celular e Extracelular, Universidade Federal Fluminense, Rua Hernani Mello 101, São Domingos, Niterói, RJ 24210-130, Brazil. E-mail: chagas.m@gmail.com

Samples of ten penises of Mediterranean buffaloes and ten penises of Red Sindhi cattle were used. The thickness of the tunica albuginea (TA), distribution of smooth muscle cells (SMC) and volume density (Vv) of elastic system fibers in TA, corpus cavernosum (CC) and corpus spongiosum (CS) were evaluated. The Vv of elastic system fibers in buffalo and bovine penis was respectively $4.07 \% \pm 0.88 \%$ and $3.36 \% \pm 1.21 \%$ in TA; $17.32 \% \pm 2.21 \%$ and $13.14 \% \pm 1.27 \%$ (CC), $26.58 \% \pm 4.31 \%$ and $31.36 \% \pm 3.67 \%$ (CS). The CC of buffalo presented higher Vv of elastic fibers than bovine, while in the CS the Vv of elastic fibers in buffaloes was smaller than in cattle. The TA thickness showed a significant difference among the species studied. The arrangement of SMC in the bovine penises and in the water buffalo suggests that this pattern is common to animals that have fibroelastic penises.
\end{abstract}

INDEX TERMS: Penis, elastic fibers, smooth muscle, collagen, cattle, water buffaloes.

RESUMO.- [Estereologia do sistema elástico e das células musculares lisas no pênis fibroelástico zebuino e bubalino.] 0 pênis dos zebuinos e bubalinos são classificados como do tipo fibroelástico, sendo grande parte de sua rigidez conferida pelas fibras colágenas e elásticas presentes na matriz extracelular. Embora alguns estudos tenham abordado estes componentes em bovinos europeus, os dados na literatura sobre zebuínos e bubalinos são escassos. Nós avaliamos a espessura da túnica albugínea, a distribuição das células musculares lisas e a densidade volumétrica (Vv) das fibras do sistema elásticona túnica albugínea, no corpo cavernoso e esponjoso do pênis de animais jovens adultos inteiros.Foram utilizados 10 fragmentos de pênis de búfalos da raça Mediterrâneo e 10 fragmentos de pênis

\footnotetext{
${ }^{1}$ Received on August 9, 2013.

Accepted for publication on December 5, 2013.

${ }^{2}$ Programa de Pós-Graduação em Medicina Veterinária, área de concentração Clínica e Reprodução Animal, Universidade Federal Fluminense (UFF), Rua Vital Brazil Filho 64, Santa Rosa, Niterói, RJ 24230-340, Brazil

${ }^{3}$ Departamento de Anatomia, Universidade Federal Rural do Rio de Janeiro (UFRRJ), Seropedica, RJ 23890-000, Brazil.

${ }^{4}$ Laboratório de Biomorfologia Celular e Extracelular, UFF, Rua Hernani Mello 101, São Domingos, Niterói, RJ 24210-130. *Corresponding author: chagas.m@gmail.com
}

de bovinos da raça Red Sindi. Os fragmentos de pênis foram processados de acordo com a técnica histológica de rotina para inclusão em parafina e corados pela Fucsina Resorcina de Weigert, Picro Sirius Red, Tricrômio de Gomori e anticorpo anti $\alpha$ actina. As fibras elásticas foram determinadas em 25 campos aleatórios de cada fragmento, utilizando o sistema teste modelo M42. A Vv das fibras do sistema elástico no pênis do búfalo e bovino foram(média e desvio padrão respectivamente) de $4,07 \% \pm 0,88$ e 3,36\% $\pm 1,21$ na túnica albugínea; $17,32 \% \pm 2,21$ e $13,14 \% \pm 1,27$ no corpo cavernoso; $26,58 \% \pm 4,31$ e $31,36 \% \pm 3,67$ no corpo esponjoso, respectivamente. Houve diferença na $\mathrm{Vv}$ das fibras elásticas entre as duas espécies, no corpo cavernoso e no corpo esponjoso. Na espessura da túnica albugínea houve diferença significativa entre o búfalo Mediterrâneo $(1,4 \mathrm{~mm} \pm 0,11)$ e o bovino Red Sindi $(1,76 \mathrm{~mm} \pm 0,23)$. Nas duas espécies, as fibras musculares lisas foram encontradas apenas associadas ao endotélio de revestimento dos seios cavernosos. Com base nestes resultados, podemos concluir que existem diferenças na proporção entre os componentes da matriz extracelular nas espécies estudadas, fato que deve ser considerado nos procedimentos clínicos e cirúrgicos veterinários e continua a ser investigado.

TERMOS DE INDEXAÇÃO: Pênis, sistema elástico, zebuíno, bubalino. 


\section{INTRODUCTION}

The penis of the domestic mammals is classified into two types, such as fibroelastic and musculocavernous, according the construction of the corpus cavernosum (CC). In fibroelastic type, penis increases in length with little modification in diameter during erection. This type is found in swne, ruminants and the rat. Man, horse, dog and rabbit have the musculocavernous type, demonstrating an increase in length and diameter during erection (Swenson 1996, Hafez 2004).

The trabeculae of the $\mathrm{CC}$ are the main structures implicated in penile erection. They are composed of endothelial cells, smooth muscle cells (SMC) and an extracellular matrix, the components of which are collagen and elastic fibers (Sattar et al. 1994, Sampaio et al. 1998, Bastos et al. 1999). The tunica albuginea (TA), a dense sheath of connective tissue involves the $\mathrm{CC}$ and also has an important role in erection, because is essential for complacency, venous occlusion, flexibility, extensibility and penile rigidity (Bitsch et al. 1990, Brock et al. 1997). The structural integrity of the corpus spongiosum (CS) is also important for the mechanism of erection since it acts synergistically with the TA and CC (Conti et al. 1988).

In the past, it was supposed that the bovine penis became rigid due to its fibrous components and the erection occurred mainly as a result of the relaxation of the retractor penis muscle. This explanation is overly simplistic, as the flaccid penis of live bull is very bendy, and it is necessary to generate a high pressure within the $\mathrm{CC}$ of the penis to allow the intromission (Ashdown et al. 1979). Studies on the ruminant penile erection suggest that the blood carried to the $\mathrm{CC}$ of the penis through deep arteries is pumped from the crural region of the penis by ischiocavernosus muscle, so it increases the pressure inside the CC (Ashdown et al. 1979). The contraction of the ischiocavernosus muscle also makes pressure on the deep veins located in the penile root, so blood is pumped within a closed system into the cavernous spaces, increasing the pressure inside the penis (Ashdown et al. 1979). The obstruction of the venous drainage helps to keep the pressure into the CC (Ashdown \& Gilanpour 1974).

There is no communication between the sinuses of the CS and the CC in the normal bull. Communications between the sinuses and the dorsal venous system can critically reduce the pressure into the $\mathrm{CC}$ during erection, leading to an erectile dysfunction condition (Ashdown et al. 1979).

According to Nascimento \& Carvalho (1993), when compared with cattle, water buffaloes present better productivity, if raised in places of difficult access, such as flooded and mud areas, where cattle would not be productive. Few studies have been conducted on the penis of water buffalo, but when compared with the bovine penis, few differences have been described (Fisher \& Bodhipaksha 1992, Escrivão et al. 2005).

Data on the collagen fibers, elastic system and smooth muscle in the CS and CC of bovine and water buffalo penises are scarce. Thus, knowledge of the structure of the penis of these species may contribute to the diagnosis and treatment of erectile dysfunction.
The aim of this study was to evaluate the thickness of the TA, the distribution of SMC and volume density (Vv) of elastic system fibers in the CS and CC of the penis of cattle and the water buffalo, performing a comparative study between both species.

\section{MATERIALS AND METHODS}

Ten penises from adult Mediterranean buffaloes (Bubalus bubalis) and ten penises from adult Red Sindhi bulls (Bos indicus) were obtained from the Federal Rural University of Rio de Janeiro for this project. After slaughter, the penises were removed and immediately fixed in $10 \%$ phosphate buffered formaldehyde solution for 24 to 48 hours. Following, five fragments were removed at the base of the penis. Subsequently, the samples were dehydrated in increasing alcohol solutions, starting with 70\% to absolute alcohol, cleared in xylene and embedded in paraffin. Each fragment originated one different section $5 \mu \mathrm{m}$ thick. The sections were initially stained with Gomori's Trichrome for detection of material featuring histological artifacts. In all sections, five random fields were analyzed, then a total of $25(5 \times 5)$ fields analyzed per evaluated penis. To evaluate the collagen fibers the sections were stained with Picrosirius red and observed under polarized light.

To assess the elastic fiber system the sections were stained with Weigert's Resorcin Fuchsin with prior oxidation by oxone. Data were expressed as volume density (\%). The images for general analysis and two-dimensional quantification were obtained in a magnification of $40 \mathrm{x}$ by using an Olympus microscope coupled to a Sony CCD video camera. The images were transferred to a Sony monitor KX14-CP1.

Randomly selected fields were then quantified using the M42 test system. Data were obtained by this the point counting planimetry method, superimposing the M42 grid on the monitor screen (Weibel et al. 1966).

The $\mathrm{Vv}$ of the histological components was calculated as $\mathrm{Vv}$ $=\mathrm{Pp} / \mathrm{Pt}$, where $\mathrm{Vv}$ is the volume density, $\mathrm{p}$ is the tissue component under consideration (elastic fibers), $\mathrm{Pp}$ is the number of test points associated with $\mathrm{p}$, and $\mathrm{Pt}$ is the total number points of the M42 grid.

\section{Statistical analysis}

Data were analyzed with Graphpad Instat (Graphpad) to verify the normal distribution. Means were compared using the unpaired $t$ test. Differences were considered significant when $\mathrm{p}<0.05$.

\section{Immunohistochemical assay}

The Avidin-Biotin technique was performed for identification of SMC, using Monoclonal anti-actin alpha-smooth muscle antibody at a dilution of 1:400 in phosphate buffered saline (A2547 - Sigma Company) as the primary antibody. The sections were dewaxed in xylene, hydrated in a decreasing series from ethanol to water and washed in phosphate buffered saline (PBS) for five minutes. Subsequently, they were treated for thirty minutes at room temperature with hydrogen peroxide $3 \%$ in methanol to block endogenous peroxidase activity. After this stage, sections were washed in PBS ( 3 changes of 5 minutes each) and incubated in a moist chamber at $37^{\circ} \mathrm{C}$ for thirty minutes with goat serum $1 \%$ in PBS. Then, they were incubated in a moist chamber at $4^{\circ} \mathrm{C}$ for 12 to 14 hours with the primary antibody. Negative controls, where primary antibody was replaced by PBS, and positive controls, using tissue fragments that display the antigens were performed for all primary antibodies.

Finally, sections were washed in PBS (3 changes of 5 minutes each) and incubated in a moist chamber at room temperature 
for thirty minutes with biotinylated secondary antibody diluted 1:100 in PBS.

\section{Thickness of the tunica albuginea}

Thickness of the TA was measured in sections stained with hematoxylin-eosin. The image processing program Image J was used for the morphometric analysis, which allows quantitative histomorphometry. The measurement was taken in three different regions of the TA and the arithmetic mean was used to obtain more accurate value. The thickness was measured in millimeters and the magnification was $2.5 \mathrm{x}$.

\section{RESULTS}

The arrangement of the elastic fibers in the TA consisted in a peripheral longitudinal and an inner transverse layer, which continued with the elastic system fibers of the trabeculae. The Vv of elastic fibers in the TA, CC and CS are listed in Table 1. There was no significant difference between the $\mathrm{Vv}$ of elastic fibers in TA of water buffalo and bovine $(p=0.1930)$. However, the CC of water buffalo presented higher $\mathrm{Vv}$ of elastic fibers than bovine $(\mathrm{p}=0.0002)$, while in the CS the $\mathrm{Vv}$ of elastic fibers of water buffalo was smaller than bovine ( $\mathrm{p}=0.0222$ ) (Fig.1).

The TA of bovine was thicker than water buffalo $(p=0.0066)$, as demonstrated in Table 2. The TA of the CC of bovine and water buffalo consisted of thick bundles of collagen fibers with ondulate shape, interspersed with elastic fibers. In both bovine and water buffalo, the TA was also divided into two layers: the inner circular and outer longitudinal (Fig.2).

Table 1. Volumetric density of elastic fibers in tunica albuginea, corpus cavernosum and corpus spongiosum of the penis of cattle and buffalo

\begin{tabular}{|c|c|c|c|c|c|c|}
\hline & \multicolumn{2}{|c|}{ Tunica albuginea } & \multicolumn{2}{|c|}{ Corpus cavernosum } & \multicolumn{2}{|c|}{ Corpus spongiosum } \\
\hline & Buffalo & Bovine & Buffalo & Bovine & Buffalo & Bovine \\
\hline Mean & $4.07 a$ & $3.36 \mathrm{a}$ & $17.32 \mathrm{~b}$ & $13.14 \mathrm{c}$ & $26.58 d$ & $31.38 \mathrm{e}$ \\
\hline SD & 0.88 & 1.21 & 2.21 & 1.27 & 4.31 & 3.67 \\
\hline Minimum & 2.61 & 1.42 & 14.51 & 5.47 & 18.56 & 27.85 \\
\hline Maximum & 5.71 & 4.76 & 21.18 & 17.37 & 35.22 & 38.79 \\
\hline
\end{tabular}

Data were expressed as percent. $S D=$ Standard deviation. $a \mathrm{p}=0.1930 ; \mathrm{b}, \mathrm{c}$ $\mathrm{p}=0.0002 ; \mathrm{d}$,e $\mathrm{p}=0.0222$.
Table 2. Thickness of the tunica albuginea of the corpus cavernosum in bovine and buffalo

\begin{tabular}{lcc}
\hline & \multicolumn{2}{c}{ Tunica albuginea } \\
\cline { 2 - 3 } & Buffalo & Bovine \\
\hline Mean & $1.45 \mathrm{a}$ & $1.76 \mathrm{a}$ \\
SD & 0.11 & 0.23 \\
Minimum & 1.30 & 1.39 \\
Maximum & 1.66 & 2.09
\end{tabular}

Data were expressed as millimeters. $\mathrm{SD}=$ Standard deviation. a $\mathrm{p}=0.0066$.

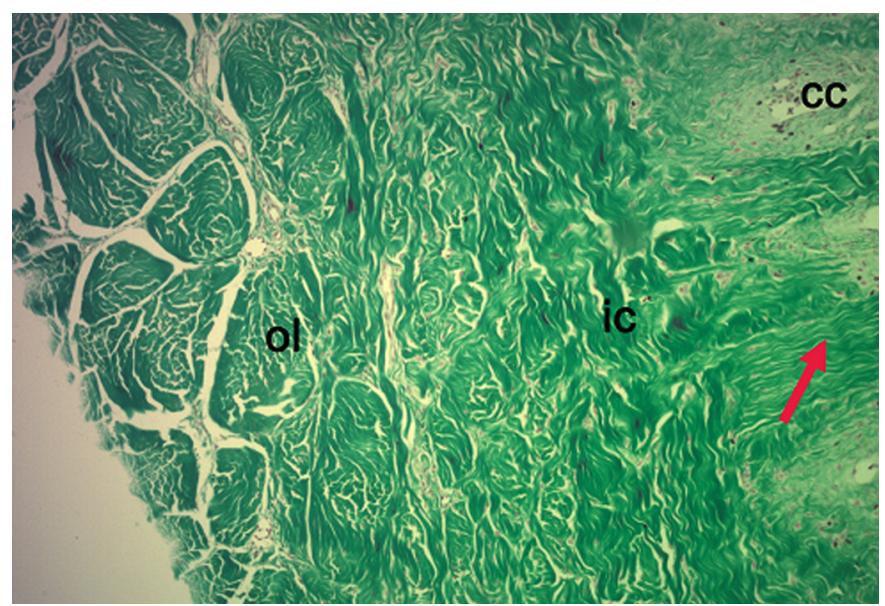

Fig.2. Tunica albuginea of corpus cavernosum (cc) from Mediterranean buffalo penis, showing its two layers: the inner circular (ic) and outer longitudinal (ol). The collagen fibers of the inner circular layer continue to corpus cavernosum trabeculae (arrow). Gomori's Trichrome, 40x.

Many collagen fibers were found in the CC and CS, even though the collagen fibers of CC were thicker than collagen fibers in CS (Fig.3)

There was a slight amount of SMC in the trabeculae of the CC of both water buffalo and bovine. It produced a subendothelial layer outlining the cavernous spaces. The fibers were positioned in the longitudinal and transverse axis of the penile shaft, and the transverse fibers were predominant. The stereological analysis of the immunostained sections showed that the SMC had a Vv of $9.645 \%$ in water buffalo and $9.625 \%$

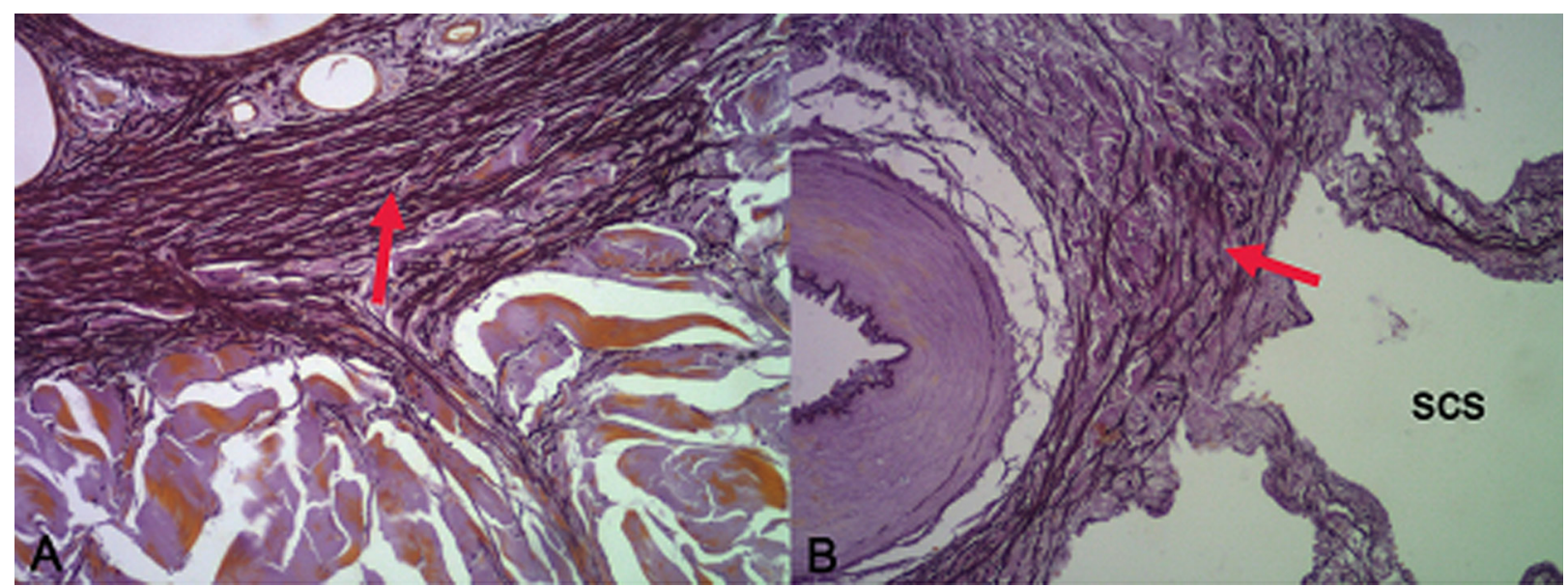

Fig.1. Light micrograph of Corpus spongiosum from (A) Red Sindhi cattle, and (B) Mediterranean buffalo penis, showing the elastic system fibers (arrows). Weigert's Resorcin Fuchsin with prior oxidation, 100x. 


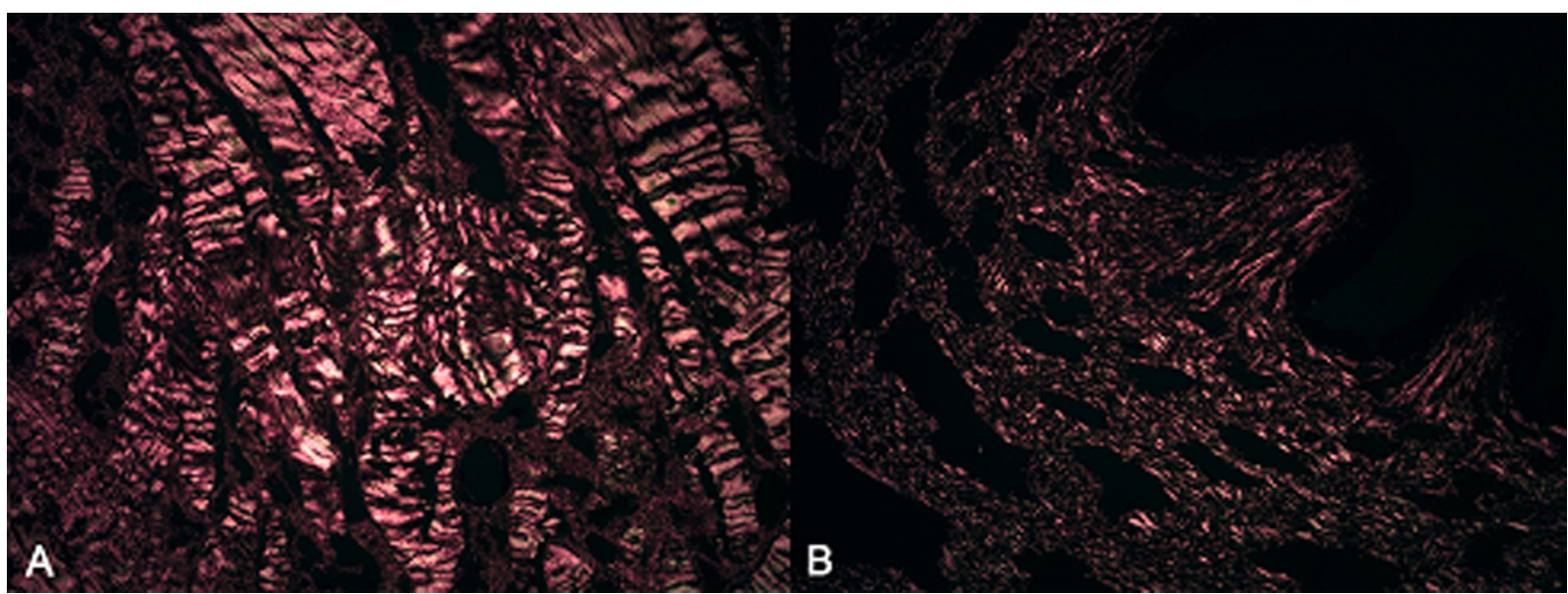

Fig.3. (A) Corpus cavernosum of Red Sindhi bovine penis and (B) corpus spongiosum of Mediterranean buffalo penis. Note the thicker collagen fibers in the corpus cavernosum of the Red Sindhi cattle penis (A) and the thinner collagen fibers in the corpus spongiosum of the Mediterranean buffalo penis (B). Picrosirius Red under polarized light, 40x.

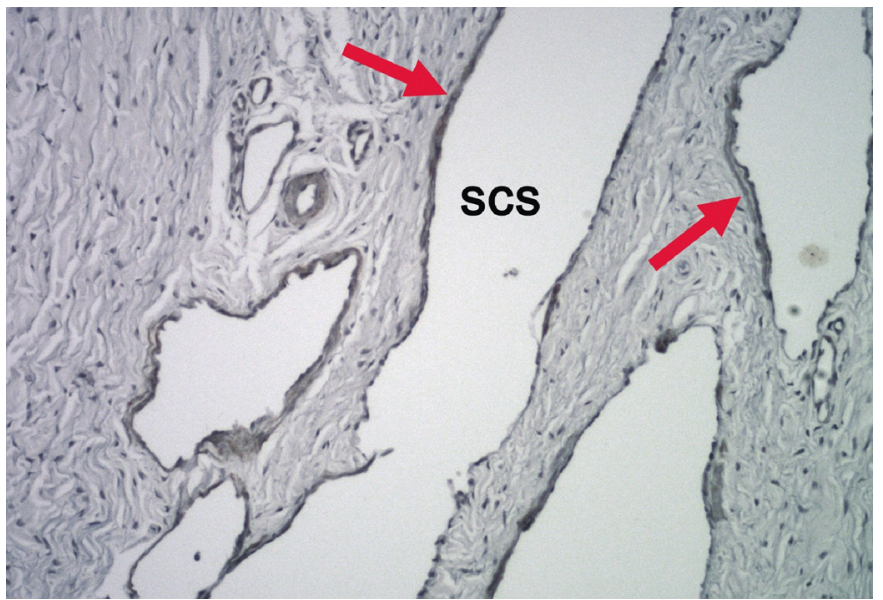

Fig.4. Corpus spongiosum of Mediterranean buffalo penis, showing the sinus of the corpus spongiosum (scs) and the smooth muscle cells (arrows) in the trabeculae subendothelial space. Avidin Biotin immunostaining anti-smooth muscle $\alpha$ actin, 100x.

Table 3. Volumetric density of smooth muscle cells in corpus cavernosum and corpus spongiosum of the penis of cattle and buffalo

\begin{tabular}{lccccc}
\hline & \multicolumn{2}{c}{ Corpus cavernosum } & & \multicolumn{2}{c}{ Corpus spongiosum } \\
\cline { 2 - 3 } \cline { 5 - 6 } & Buffalo & Bovine & & Buffalo & Bovine \\
\hline Mean & $9.645 \mathrm{a}$ & $9.625 \mathrm{a}$ & & $2.856 \mathrm{~b}$ & $3.046 \mathrm{~b}$ \\
SD & 0.9067 & 0.7297 & & 0.4488 & 0.7166 \\
Minimum & 8.14 & 9.044 & & 2.38 & 2.38 \\
Maximum & 10.948 & 10.472 & & 3.332 & 4.284
\end{tabular}

Data were expressed as percent. $\mathrm{SD}=$ Standard deviation. ${ }^{\mathrm{a}} \mathrm{p}=0.8785$, ${ }^{\mathrm{b}} \mathrm{p}=0.6752$.

in bovine (Table 4). There was no significant difference between the Vv of SMC in water buffalo and bovine $(p=0.8785)$.

The CS presented scattered SMC in both animals. They were located only in the narrow subendothelial space of some trabeculae and also the wall of small vessels (Fig.3). The stereological analysis revealed that the SMC had a Vv of $2.856 \%$ in water buffalo and $3.04 \%$ in bovine (Table 3 ). There was no difference between $\mathrm{Vv}$ of SMC in bovine and buffalo ( $\mathrm{p}=0.6752)$.

\section{DISCUSSION}

The fibroelastic penis of cattle and water buffalo is an organ of great interest in animal breeding, due to the outstanding role played by the fibrous component of the extracellular matrix of the CC for penile erection (Young et al. 1977, Ashdown et al. 1979). Tissues that are constantly submitted to tensile stretch, present a significant elastic system fibers (Cotta-Pereira 1976). Collagen is stabilized by elastic fibers, which are characterized by their flexibility and extensibility (Kreis \& Vale 1993). The location and arrangement of elastic fibers are related to function and mechanical properties of different parts of the tissue (Haralson \& Hanssel 1995). The study described qualitatively and quantitatively the elastic system fibers and the SMC in bovine penis and of the water buffalo to set a histological pattern of these elements for those species.

Regarding the $\mathrm{Vv}$ of elastic system fibers in the TA, no significant difference between water buffalo and cattle was found, suggesting that this structure, at least concerning on elasticity, plays a similar role in both species. However, the TA of cattle $(1.76 \mathrm{~mm}$ in mean) was thicker than in water buffalo (1.45 $\mathrm{mm}$ in mean). Ashdown \& Smith (1969) reported values around $3 \mathrm{~mm}$ to the thickness of the TA of European cattle. This finding is higher than our results for zebu cattle $(1.76 \mathrm{~mm})$. This difference between European and zebu cattle can be attributed to the breed difference or only to the different size of animals.

The different thickness of the TA may be related to increased pressure generated within the CC of the penis of the animal, because it serves to support and protect vessels and nerves, that might otherwise be squeezed or stretched by the high pressure inside the CC during erection (Goldstein et al. 1985). Therefore, the TA, which surrounds the trabeculae of the $\mathrm{CC}$, has an important role in the mechanism of erection and is essential for complacency, venous occlusion, flexibility, extensibility and penile rigidity (Bitsch et al. 1990, Goldstein \& Padma-Nathan 1990). The main structures to promote such function are the collagen and elastic fibers. Thus, any structural damage can immediately affect the penile function. 
Changes in the quantity and morphology of collagen and elastic fibers may result of diseases that lead to erectile dysfunction, such as priapism and Peyronie's disease (Brock et al. 1997, Van der Horst et al. 2003, Tazi 2009, Costa et al. 2010), and other disorders, such as preputial prolapse, phimosis, balanitis, fibropapilloma, acropostitis and penile deviation (Rabelo et al. 2008). Elastic fibers stabilize the collagen and are characterized by elasticity and extensibility, as one of the properties of elastin is to promote the support and elasticity (Cotta-Pereira et al. 1976, Kreis \& Vale 1993). Changes in the architecture of elastic fibers or loss of function are pathological features found in a number of degenerative and inflammatory diseases (Haralson \& Hanssel 1995).

The structural description and quantification of fibrous elements of the extracellular matrix have already proved to be an effective method for the evaluation of morphological and functional changes associated with pathological conditions in humans and animal models (Siracusano et al. 1996, Babinski et al. 2005, Maia et al. 2006).

The organization of collagen fibers in the TA of the CC of cattle and water buffalo are in agreement with previous reports on the fibroelastic penis of the rat, regarding its constitution: lots of thick bundles of collagen fibers with undulant shape, interspersed with elastic fibers (Bitsch et al. 1990, Calabrò et al. 1996). The TA of cattle and the water buffalo is divided into two layers: the inner circular and outer longitudinal, similar to the arrangement observed in the TA of rats (Pinheiro et al. 2000), humans (Akkus et al. 1997) and mice (Nakano 1995b).

The characterization of collagen in sections stained by Picrosirius red and observed under polarized light shown in both bovine and water buffalo predominance of red color, normally associated with type I collagen fibers. Type I collagen is the most commonly found in the general connective tissues and form thicker fibrils, whereas collagen type III is located in specific organs and around muscular fibers. The collagen type III forms thinner fibrils, also called reticular fibers, normally showing greenish appearance when stained by Picrosirius red and observed under polarized light (Van der Rest \& Garrone 1991). Although the type I collagen fibers were predominant in both CC and CS of cattle and water buffalo, the fibers in CC were thicker than in CS, suggesting a possible difference in the functional properties of CC and CS.

The arrangement of the collagen fibers in the bovine penis is very important. To reinforce this idea, Ashdown et al (1968) observed in the integument of the penis a clear spiral pattern of collagen fibers. This spiral arrangement of collagen fibers suggests, according to Ashdown et al. (1968), a satisfactory anatomical explanation for the spiral deviation that occurs at the free extremity of the penis when it is erect. This spiral arrangement of collagen fibers in the integument of the penis was found in adult animals, young animals and fetuses, demonstrating to be a congenital characteristic and not acquired during adulthood.

The arrangement of the elastic fibers in the TA consisted in a peripheral longitudinal and an inner transverse layer, which continued with the elastic system fibers of the trabeculae. This way of distribution of the elastic fibers is similar to that described in human fetuses and adults ( $\mathrm{Hsu}$ et al. 1994, Bastos \& Costa 1998), in young adult rats (Pinheiro et al. 2000) and rabbits (Maia et al. 2006).

The water buffalo had a higher elastic system fibers in the CC than the bovine species, suggesting that the elastic system in this animal may play an utmost important role. The smaller amount of elastic fibers in the CC of the bovine penile could be related to the thicker TA. The organization of collagen bundles in two layers in the TA seems to contribute to a better resistance to stretching process, i.e., could enhance elasticity during erection, compensating the lower amount of elastic system fibers in the CC. When the Vv of elastic system fibers in the CC is compared between other species, it shown about 5\% in rat (Pinheiro et al. 2000), $11 \%$ in wild boar (Babisnki et al. 2005), 9\% in man (Sattar et al. 1994, Bastos et al. 2004) and 25.1\% in rabbit (Maia et al. 2006), while in bovine and water buffalo the Vv of elastic fibers in the CC is $13.14 \%$ and $17.32 \%$, respectively.

Regarding the SMC, immunohistochemistry revealed the presence of these cells only as a thin layer lining the lumen of the CC. This finding is in agreement with previous descriptions of CC of adult rat (Pinheiro et al. 2000), which had the Vv of $9.1 \%$ of SMC in the CC, similar amount found in bovine (9.625\%) and water buffalo (9.645).

The amount and organization of SMC in the musculocavernous penis are markedly different from those found in the fibroelastic penis. The SMC in musculocavernous penile occupy a significant space and are uniformly distributed in the total area of the trabeculae of the CC. In humans, these cells represent 34 to $52 \%$ of the total area of the CC (Goldstein \& Padma-Nathan 1990, Nehra et al. 1998), in rabbits these cells represent $49.28 \%$ of the total area of the CC (Abidu-Figueiredo et al. 2010). The SMC are capable to maintain muscle tonus, which is very important in regulating the luminal diameter of tubular structures, such as the vascular penis. An increase in tonus of muscle fibers arranged circularly reduces the diameter of the lumen and vice versa (Comarck 1991). The CS of the bovine penis presented more elastic fibers than the one of water buffalo penis. The presence of elastic system fibers is more expressive in the trabeculae of CS than in the trabecula of CC of both bovine and water buffalo penis. Some authors have reported the same difference in man (Conti \& Virag 1989, Hsu et al. 1994), in boar (Babisnki et al. 2005) and rabbit (Maia et al. 2006).

When comparing the arrangement and amount of the collagen fibers into the TA and trabeculae of the CS and into the TA and trabeculae of the CC, the difference seems to be related to the hemodynamic process, which occurs in the $\mathrm{CS}$ and the CC during erection. In the CS, the venous drainage is not completely compressed against the TA. Thus, the pressure remains low and the CS does not become completely rigid, even during a full erection, allowing the emission of semen through the urethra during ejaculation (Nakano 1995a). In the CS of the water buffalo and cattle, SMC were not numerous, therefore it has little significance in the structural organization of the CS. Similar amount of these fibers was found in CS of adult rats (Pinheiro et al. 2000). 


\section{CONCLUSIONS}

The present study presents the quantification of elastic system fibers and SMC for the first time in the penis of Red Sindhi cattle and Mediterranean buffalo.

The arrangement of SMC in the penis of cattle and water buffalo suggests that this pattern is common to animals that have a fibroelastic penis, but significant differences were observed between the bovine and the buffalo species for the distribution of elastic system fibers in CC and CS, and the thickness of the TA.

Acknowledgements.- This study was supported by grants from the Foundation for Research Support of Rio de Janeiro (FAPERJ), Brazil.

\section{REFERENCES}

Abidu-Figueiredo M., Ribeiro I.C.A., Chagas M.A., Cardoso L.E.M., Costa W.S. \& Sampaio F.J.B. 2010. The penis in diabetes: structural analysis of connective tissue and smooth muscle alterations in a rabbit model. BJU International 108:400-404.

Akkus E., Carrier S., Baba K., Hsu G.L., Padma-Nathan H., Nunes L. \& Lue T.F. 1997. Structural alterations in the tunica albuginea of the penis: impact of Peyronie's disease, ageing and impotence. Brit. J. Urology 79:47-53.

Ashdown R.R., David J.S.E. \& Gibbs C. 1979. Impotence in the bull. 1. Abnormal venous drainage of the corpus cavernosum penis. Vet. Rec. 104(19):423-428.

Ashdown R.R. \& Gilanpour H. 1974. Venous drainage of the corpus cavernosum penis in impotent and normal bulls. J. Anatomy 117:159-170.

Ashdown R.R., Ricketts S.W. \& Wardley R.C. 1968. The fibrous architecture of the integumentary coverings of the bovine penis. J. Anatomy 103(3):567-572.

Babinski M.A., Brito-Gitirana L., Chagas M.A., Abidu-Figueiredo M., Costa W.S. \& Sampaio F.J. 2005. Immunohistochemical analysis of smooth muscle cells and volumetric density of the elastic system fibers of wild boar (Sus scrofa) penis. Anim. Reprod. Sci. 86(3/4):317-328.

Bastos A.L., Costa W.S. \& Sampaio F.J.B. 2004. Concentration of elastic fibers in the male urethra during human fetal development. BJU International 94:620-623.

Bastos A.L., Costa W.S., Cardoso L.E. \& Sampaio F.J.B. 1999. Collagen and elastic fibers of the penis in human fetuses with 28 weeks postconception. Eur. Urology 34:158-163.

Bitsch M., Kromann-Andersen B., Schou J. \& Sjontoft E. 1990. The elasticity and the tensile strength of tunica albuginea of the corpora cavernosa. J. Urology 143:642-645.

Brock G., Hsu G.L., Nunes L., von Heyden B. \& Lue T.F. 1997. The anatomy of the tunica albuginea in the normal penis and Peyronie'sdisease. J. Urology 157:276-281.

Calabrò A., Italiano G., Pescatori E.S., Marin A., Gaetano O., Abatangelo G., Abatangelo G. \& Pagano F. 1996. Physiological aging and penile erectile function: a study in the rat. Eur. Urology 29:240-244.

Conti G. \& Virag R. 1989. Human penile erection and organic impotence; normal histology and histopathology. Urologia Internationalis 44:303308.

Conti G., Virag R. \& von Niderhäusern W. 1988. The morphological basis for the polster theory of penile vascular regulation. Acta Anatomica 133:209-212.

Cormack D.H. 1987. Ham's Histology. J.B. Lippincott Company, Philadelphia, p.43.

Costa W.S., Felix B., Cavalcanti A.G., Medeiros Jr J. \& Sampaio F.J.B. 2010. Structural analysis of the corpora cavernosa in patients with ischaemic priapim. BJU International 105(6):838-841.

Cotta-Pereira G., Guerra R.F. \& Bittencourt-Sampaio S. 1976. Oxytalan, eulaunin and elastic fibers in the human skin. J. Invest. Dermatol. 66:143-148.

Escrivão S.C., Nascimento E.F., Gheller V.A. \& Araújo D.K.G. 2005. Patologia do sistema genital na espécie bubalina (Bubalus bubalis). Revta Bras. Reprod. Anim. 29(2):74-76.

Fisher H. \& Bodhipaksha P. 1992. Reproduction in swamp buffaloes, p.153-169. In: Tulloh N.M. (Ed.), Buffalo production. Elsevier Science Publishers, Amsterdam.

Goldstein A.MB. \& Padma-Nathan H. 1990. The microarchitecture of the intracavernosal smooth muscle and the cavernosal fibrous skeleton. J. Urology 144:1144-1146.

Goldstein A.M.B., Meehan J.P., Morrow J.W., Buckley P.A. \& Rogers F.A. 1985. The fibrous skeleton of the corpora cavernosa and its probable function in the mechanism of erection. Brit. J. Urology 57:574-578.

Hafez B. 2004. Reprodução Animal. Manole, Rio de Janeiro. 277p.

Haralson M.A. \& Hanssel J.R. 1995. Extracellular Matrix: a practical approach. Oxford University Press, Oxford, p.1-20.

Hsu G.L., Brock G., von Heyden B., Nunes L., Lue T.F. \& Tanagho E.A. 1994. The distribution of elastic fibrous elements within the human penis. Brit. J. Urology 73:566-571.

Kreis T. \& Vale R. 1993. Guidebook to the Extracellular Matrix and Adhesion Proteins. Oxford University Press, Oxford, p.40-51.

Maia R.S., Babinski M.A., Abidu-Figueiredo M., Chagas M.A., Costa W.S. \& Sampaio FJ.B. 2006. Concentration of elastic system fibers in the corpus cavernosum, corpus spongiosum, and tunica albuginea in the rabbit penis. Int. J. Impotence Res. 18(2):121-125.

Nakano T. 1995a. Collagen fibrillar arrangement in the corpus cavernosum/ corpus spongiosum of mice. Adv. Contracept. Deliv. Syst. 11:131-134.

Nakano T. 1995b. Three-dimensional architecture of collagen fibrils in the mouse corpus cavernosum penis. Acta Anatomica 152:215-223.

Nascimento C.N.B. \& Carvalho L.O.D.M. 1993. Criação de búfalos: alimentação, manejo, melhoramento e instalações. Embrapa/SPI, Brasília. 403p.

Nehra A., Azadzoi K.M., Moreland R.B., Pabby A., Siroky M.B., Krane R.J., Goldstein I. \& Udelson D. 1998. Cavernosal expandability is na erectile tissue mechanical property which predicts trabecular histology in na animal modelo of vasculogenic erectile dysfunction. J. Urology 159:2229-2236.

Pinheiro A.C.A.D., Costa W.S., Cardoso L.E.M. \& Sampaio F.J.B. 2000. Organization and relative content of smooth muscle cells and extracellular matrix components in the corpus cavernosum of the rat penis. J. Urology 164:1802-1806.

Rabelo R.E., Silva L.A.F., Brito L.A.B., Silva O.C., Moura M.I., Daleck C.R. \& Damasceno A.D. 2008. Desmotomia apical experimental em bovinos e efeitos na indução do desvio peniano. Revta Vet. Zootec. 15(2):313-324.

Sampaio F.J.B., Pinto J.L.F., Costa W.S. \& Pereira M.J.S. 1998. Quantitative analysis of smooth muscle fibers in corpus cavernosum of human fetuses. J. Urology 159:2226-2228.

Sattar A.A., Wespes E. \& Schulman C.C. 1994. Computerized measurement of penile elastic fibres in potent and impotent men. Eur. Urology 25(2):142-144.

Siracusano S., Bosinco L. \& Marras V. 1996. Preliminary reports on morphological and ultrastructural changes in the corpora cavernosa of the rat after chronic arterial obstruction. Archs Espanoles Urologia 49:191-195.

Swenson M.J. 1996. Duke's Fisiologia dos Animais Domésticos. Guanabara Koogan, Rio de Janeiro, p.57.

Tazi I. 2009. Priapism as the first manifestation of chronic myeloid leukemia. Annals of Saudi Medicine 29:412.

Van der Rest M. \& Garrone R. 1991. Collagen family of proteins. Faseb Journal 5:2814-2823.

Van der Horst C., Stuebinger H., Seif C., Melcior D.E., Martínez-Portillo F.J. \& Juenemann K.P. 2003. Priapism: Etiology, pathophysiology and management. Int. Braz. J. Urol. 29:391-400.

Weibel E.R., Kistler G.S. \& Escherle W.F. 1966. Practical stereological methods for morphometric cytology. J. Cell Biol. 30:23-38.

Young S.L., Hudson R.S. \& Walker D.F. 1977. Impotence in bulls due to vascular shunts from the corpus cavernosum penis. J. Am. Vet. Med. Assoc. 171(7):643-648. 